\title{
STUDY OF PULMONARY FUNCTION IMPAIRMENT BY SPIROMETRY IN POST PULMONARY TUBERCULOSIS
}

K. Sailaja ${ }^{1}$, H. Nagasreedhar Rao ${ }^{2}$

\section{HOW TO CITE THIS ARTICLE:}

K. Sailaja, H. Nagasreedhar Rao. "Study of Pulmonary Function Impairment by Spirometry in Post Pulmonary Tuberculosis". Journal of Evolution of Medical and Dental Sciences 2015; Vol. 4, Issue 42, May 25;

Page: 7365-7370, DOI: $10.14260 /$ jemds/2015/1068

ABSTRACT: Often pulmonary Tuberculosis patients declared cured will have residual respiratory disability due to impaired pulmonary function that will have impact on their daily activities. OBJECTIVES: To study pulmonary function impairment in treated pulmonary tuberculosis patients. DESIGN: Prospective observational study-conducted from Jan 2014 to Dec 2014. METHODOLOGY: Adult patients treated for pulmonary Tuberculosis under DOTS or Daily regimen and declared cured and presenting with dyspnea are studied. History regarding smoking, bronchial asthma, Interstial lung disease, occupational exposure are taken and if present are excluded from the study. History and clinical features suggestive of reactivation of Tuberculosis if present also excluded from the study. Simple spirometry done to all selected patients. Pre and post bronchodilator $\mathrm{FEV}_{1}, \mathrm{FVC}, \mathrm{FEV}_{1} / \mathrm{FVC}$ recorded. RESULTS: 56 patients satisisfying the criteria are included in the study. In $62.5 \%$ Obstructive, $16.07 \%$ Restrictive and 21.42\% Mixed abnormality detected. CONCLUSIONS: Obstructive, Restrictive and mixed type pattern are seen in treated pulmonary Tuberculosis patients but Obstructive patternof various degree is more common.

KEYWORDS: Tuberculosis, Pulmonary Function Test, Obstructive, Restrictive, Mixed.

INTRODUCTION: Pulmonary Tuberculosis patients who have taken complete course of Anti tuberculosis treatment (ATT)and cured, ${ }^{1}$ with sputum negative for Acid Fast Bacilli (AFB)and X ray chest showing inactive lesions are frequently left with respiratory disability due to impairment in pulmonary function and present to pulmonary medicine department with dyspnea.

As India accounts for $26 \%$ of Global Tuberculosis burden, ${ }^{2}$ post Tuberculosis pulmonary impairment may cause significant morbidity and economic loss. Tuberculosis affects lung function due to fibrosis, cavitation, bronchiectasis, pleural thickening etc. causing restrictive abnormality but obstructive abnormality also described.3,4,5 Post tubercular impairment can manifest as obstructive airway disease, mixed defect, or as pure restrictive defect. ${ }^{5}$ Post pulmonary tuberculosis observed to be an aetiological factor for COPD,5-8 and previous tuberculosis considered as risk factor for COPD.7-11

METHODOLOGY: Carried out in Pulmonary Medicine Department from Jan 2014 to Dec 2014 Kurnool Medical College Kurnool.

\section{Inclusion Criteria:}

1. Adult $>18$ yearsage.

2. Pulmonary tuberculosis patients who has taken full course of ATT.

3. Presenting with Dyspnea, cough.

4. Sputum AFB - Negative .

5. X ray chest - normal, or showing inactive lesions, sequalae of TB like fibrosis, cavity, calcifications, bronchiectactic changes.

6. Non smoker. 


\section{Exclusion Criteria:}

1. Smoker - present and past.

2. Bronchial Asthma.

3. X ray chest - suggestive of active lesions.

4. Sputum AFB -Positive.

5. History and clinical features suggestive of active pulmonary tuberculosis.

6. Interstitial lung diseases.

7. Cardiac diseases.

8. Anemia.

9. History of occupational lung diseases.

Data regarding age, gender, diagnosis, time of completion of anti TB treatment, smoking history, occupational history were recorded. X ray chest, sputum AFB, ECG, Hb\%done.

56 patients satisfying the criteria are subjected to the spirometry after taking consent. 38 were males and 18 were females (Table: 1). The age of patients was ranging from 21 years to 70 years. 41(73.21\%) cases occurring in less than 50 years. (Table: 2) Spirometry was done when patient came with the complaints of dyspnea. The duration of interval between completion of ATT and development of dyspnea is variable ranging from 1 month to 10 years, in $40(71.42 \%)$ occurring within 5 years of completion of treatment (Table: 5 ).

Spirometry was done. The technique explained to the patient and three attempts were recorded and the best of three considered if the variation between two readings is less. FEV 1 , FVC, $\mathrm{FEV}_{1} / \mathrm{FVC}$ recorded. Salbutamol inhaler given and waited for $30 \mathrm{~min}$. Post bronchodilator test recorded. The reversibility In $\mathrm{FEV}_{1}$ more than $12 \%$ or $200 \mathrm{ml}$ were excluded. The readings are classified as obstructive, restrictive and mixed. Obstructive pattern again divided into mild, moderate \& severe.

RESULTS: Total 56 patients are taken into the study.

\begin{tabular}{|c|c|c|}
\hline & No. cases & Percentage \\
\hline Male & 38 & 67.85 \\
\hline Female & 18 & 32.14 \\
\hline Total & $\mathbf{5 6}$ & \\
\hline
\end{tabular}

Table 1: Sex wise distribution of patients

Among total cases 38(67.85\%)are males and 18(32.14\%) are females.

\begin{tabular}{|c|c|c|}
\hline Age & Number of patients & Percentage \\
\hline $21--30$ & 16 & 28.57 \\
\hline $31--40$ & 11 & 19.64 \\
\hline $41--50$ & 14 & 25.00 \\
\hline $51--60$ & 11 & 19.64 \\
\hline $61--70$ & 4 & 7.14 \\
\hline
\end{tabular}

Table 2: Age wise distribution of cases 
Among 56 cases 41(73.21\%)cases are less than 50 years.

\begin{tabular}{|c|c|c|}
\hline Type of impairment & Number of cases & Percentage \\
\hline Obstructive & 35 & 62.5 \\
\hline Restrictive & 9 & 16.07 \\
\hline Mixed & 12 & 21.42 \\
\hline \multicolumn{2}{|c|}{ Table 3: Type of Pulmonary Impairment } \\
\hline
\end{tabular}

Among 56 cases 35 (62.5\%)showed Obstructive pattern, 9 (16.07\%)cases showed Restrictive pattern and 12 (21.42\%)cases showed mixed pattern abnormality.

\begin{tabular}{|c|c|c|}
\hline Degree of Obstruction & Number of Cases & Percentage \\
\hline Mild & 12 & 34.28 \\
\hline Moderate & 18 & 51.42 \\
\hline Severe & 5 & 14.28 \\
\hline \multicolumn{2}{|c|}{ Table 4: Severity of Obstruction } \\
\hline
\end{tabular}

Among 35 cases of Obstruction 12(34.28\%)showed mild, 18(51.42\%)cases showed Moderate, $5(14.28 \%)$ cases showed severe obstruction.

\begin{tabular}{|c|c|c|}
\hline $\begin{array}{c}\text { Interval of treatment Completion } \\
\text { and Dyspnea Development }\end{array}$ & No. of Cases & Percentage \\
\hline < 1 year & 11 & 19.64 \\
\hline 1 to 2 years & 13 & 23.21 \\
\hline 2 to 3 years & 8 & 14.28 \\
\hline 3 to 4 years & 4 & 7.14 \\
\hline 4 to 5 years & 4 & 7.14 \\
\hline 5 to 10 years & 16 & 28.57 \\
\hline
\end{tabular}

Table 5: Depicts the interval of treatment completion and dyspnea development

Among 56 cases 40(71.42\%) developed dyspnea within 5 years of stopping Anti tuberculosis treatment.

DISCUSSION: Anti tuberculosis treatment improves lung function in pulmonary tuberculosis patients but a proportion of patients left with residual pulmonary impairment.5,12,13,14,15 These patients come to Pulmonary medicine department with dyspnea. Simple spirometry was done to study the type of pulmonary impairment in selected patients.

All 3 types of pulmonary function impairment occured in the study group indicating the cause for the dyspnea may be any one of it. In this study the pattern of Pulmonary function impairment is seen as $62.5 \%$ obstructive, 16.07 restrictive and $21.42 \%$ mixed (Table :3). 
In our study obstructive defect is more commonly seen (62.5\%)in consistent with previous studies.12,16,17,18 Among 35 cases of Obstruction 12(34.28\%)showed mild, 18(51.42\%)cases showed Moderate, 5(14.28\%) cases showed severe obstruction (Table :4).

According GOLD workshop summary chronic bronchitis and emphysema can occur as complication of pulmonary tuberculosis.6,19 A study performed to assess the impact of Pulmonary tuberculosis as prevalence of COPD found that the prevalence of COPD increases to 3.7 to $5 \%$ by including participants with past history of TB treatment. ${ }^{20}$ Pulmonary function impairment as a complications of TB manifest as various pattern but mainly as airflow limitation.9,21 In PLATINO study spirometric indices compared many subjects with and without diagnosis of Tuberculosis. With Tuberculosis performed less well although relative difference tend to be greater for FEV 1 than FVC 16. History of TB was clearly associated with more severe grades of obstruction.

In our study restrictive defect is seen in $16.07 \%$ cases. Some studies found restrictive lung disease as most common followed by obstructive defect.14,15 Another study found that after 15 years follow up of patients there was a higher decline in FVC than $\mathrm{FEV}_{1}{ }^{22}$ Extensive disease may produce restrictive changes due to lung parenchymal destruction. In $21.42 \%$ cases both obstructive and Restictive(mixed) pattern is seen, $73.21 \%$ cases occured in less than 50 years (Table:2) economically earning members ${ }^{2}$ indicating that it may cause significant loss of the income to the families. post pulmonary impairment causes significant loss in income as more number of pulmonary tuberculosis cases notified in 2012 are between 15-44yr age, economically earning members. ${ }^{2}$ In $71.42 \%$ of cases Dyspnea developed within 5 years of stopping of ATT (Table :5). The loss of lung function was highest within 6 months of diagnosis of pulmonary tuberculosis and stabilized after 12 months when loss is considered as chronic. 16

Anti tuberculosis treatment improves lung function in pulmonary tuberculosis patients but a proportion of patients left with residual pulmonary impairment, 5,12,13,14,15 due to parenchymal fibrosis, cavitation, bronchiectasis, pleural thickening etc. Nefadov \& Popova attributed that the main cause of better lung function was resolution of fresh inflammatory changes and that of worse lung function was cicatricial transformation of lung tissue.23,24 Similar to smoking TB increases activity of matrix metallo proteinase enzymes contributing to pulmonary damage. ${ }^{25}$ Pulmonary dysfunction was found by Nefadov \& Simirnova as functional changes in lung tissue by hyperinflation and restriction, change in elasticity, disorders of bronchial patency, and disorders of gas exchange. ${ }^{14}$

Post tubercular pulmonary impairment emerges as distinct entity ${ }^{26,27}$ in various pattern but mainly as airflow limitation, ${ }^{10}$ andprevious Tuberculosis is considered as risk factor for COPD 7-11 Further research required to understand the mechanism of development of obstructive defect in pulmonary tuberculosis.

LIMITATIONS: Sample size is small and only those who attended the pulmonary medicine department are taken into the study so may not reflect the total treated patients in community. Not correlated with original chest radiograph or sputum AFB at the time of starting Anti tuberculosis treatment.

CONCLUSION: Pulmonary tuberculosis causes significant impairment of lung function of all three types but mainly as obstructive abnormality due to lung destruction and inflammation. So early diagnosis and treatment of Tuberculosis decreases the post tuberculosis impairment. As previous 
Tuberculosis is considered a risk factor for COPD by controlling tuberculosis the prevalence of COPD also can be reduced.

\section{REFERENCES:}

1. tbcindia.nic.in/pdfs/RNTCP\%20at\%20a\%20glance.pdf RNTCP at a Glance

2. WHO Library cataloguing-in-publication data: chapter 2 ;The burden of disease caused by TB. Global Tuberculosis Report - 2013

3. GlobalHallettwy, Maslin cJ. The different obstructive Pulmonary syndrome in a tuberculosis sanitorium etiological factors. Ann intern Med 1961; 54: 1146 - 1155.

4. Wright Gw. Tuberculosis and Pneumonia. In Fern wo, Rahn H eds Handbook of physiology, Washington DC, American Physilogical society; 1965, 1615 - 1622.

5. S.K.Verma, S. Kumar, Kiran Vishnu Narayan, R. Sodhi. Post Tubercular Obstuctive Airway Impairment Review article. Indian J Allergy Asthma Immunol 2009; 23 (2): 95-99.

6. Plit ML, Anderson R, Van Rensburg CEJ, Page-shipL, Blott JA, Fresen JL, Feldman C. Influence of antimicrobial chemotherapy on spirometric parameters and pro inflammatory indices in severe Pulmonary tuberculosis. EurRespir j 1998; 12: 351 - 356.

7. Bill B Brashier, Rahul Kodgule, Risk factors and Pathophysiology of COPD; Supliment to JAPI. February 2012; Vol. 60.

8. Salvi SS, Barness PJ, Chronic obstructive pulmonary disease in non smokers. Lancet 2009; 374 : $733-743$.

9. Jung KH, Kim SJ, Shine, Kim JH The often neglected impact of Pulmonary tuberculosis on prevalence of COPD. Am Respcrit care med 2008; 178 -431 author reply $432-433$.

10. Hassan IS, Al-jahdali HH, Obstructive airway disease in patients with significant post TB lung scarring. Saudi Med J 2005; 26; 1155 - 7.

11. Mannino DM, Buist AS. Global burden of COPD: risk factor prevalence, and future trends. Lancet 2007; 370: 765-73.

12. Lee $\mathrm{JH}$, chang $\mathrm{JH}$, Lung function in patients with chronic airflow obstruction due to tuberculosis destroyed lung Respir. Med 2003: 97; 1237 - 42.

13. Mikhail Chushkin, MD; SergryYartsev, MD; DmitriyZhutikov, MD; Elena Bogorodskaya, MD; Sergey Smerdin, MD The impairment of Respiratory Function in Patients with Treated Pulmonary Tuberculosis Chest 2011; 140 (4_MeetingAbstracts): 786A. doi: 10. 1378/chest. 1083625.

14. Nefedov VB, Smirnova DG, Disorders of pulmonary functionin patients with destructive tuberculosis .Probl Tuberk 1991; 11: 51-4.

15. Verma SK, Narayan KV, Kumar S. Astudy on prevalenc of obstructive airway disease among post pulmonary tuberculosis patients. Pulmon 2009; 11 (1): 4-7. 27

16. A.M.B.Menezes, P. C. Hallal, R. Perez-Padilla, J. R. B. , Jardim A. Muino, M. V. Lopez et al. The Latin American Project for the investigation of obstructive lung disease (PLATINO)Team. Tuberculosis and airflow obstruction evidence from PLATINO study in Latin America EurRespir.J 2007;30:1-6.

17. Patricio Swimenez P, Vivianne, Torresa, PavlaLehmenn F, Elisa Hernandez C, Mauricio, Alvanrez $\mathrm{M}$, Monica Menesses $\mathrm{M}$ et al. Chronic airway obstruction in patients with tuberculosis sequale: A comparision with COPD Rev chilEntRespir 2006; 22; 98 - 104. 


\section{ORIGINAL ARTICLE}

18. Snider GL, Doebor L, Demas TA, Shaw AR- American review of respiratory diseases 1971: 103; 625-640.

19. Pavwels RA, Buist AS, Carverley PM, Jenkins CR, Hurd SS. GOLD scientific committee. Global initiative for COLD(GOLD)workshop summary. Am J Respircrit care Med 2001: 163: 1256-76 Comment in: p; 1047-8.

20. KIM SJ , SUK MH, Choi HM, Kimm KC, Jung KH, Lee Sy, et al The local prevalence of COPD by Post bronchodialator GOLD criteria in Korea. Int J Tuberc Lung Dis 2006; 10: 1393-8.

21. Rabe KF, Hurd S, Anzueto A, Barnes PJ, Buist SA, Carverley P, et al. Global initiative for Chronic obstructive lung disease. Global strategy for the diagnosis, management, and prevention of chronic obstructive pulmonary disease: GOLD executive summary. Am J Respircrit care med 2007; 176: 532 - 55. EPub 2007 May 16.

22. Vargha \& fifteen years follow up of lung function in obstructive and non obstructive pulmonary tuberculosis. Acta Med Hung 1983 40; $271-6$.

23. Nefedov VB, Popova IA study in patients with recurrent tuberculosis and ineffective primary treatment in intensive phase of controlled chemotherapy .ProblTuberk 2002; 12: 29 - 32.

24. Hnizdo E, Singh T, Churchyard GJ, chronic pulmonary function impairment caused by initial and recurrent Pulmonary tuberculosis following treatment. Thorax 2000; 55; 32 - 38.

25. Elllington PT, Friedland JS, Matrix metalloproteinases in destructive pulmonary pathology. Thorax 2006; 61; $251-266$.

26. Macnee W, chronic bronchitis\&emphysema, Seaton A, Seaton D, Leitch AG Crofton Douglas Respiratory Diseases, United Kingdom; Black well science 2002: pp 616-617.

27. Leitch AG Pulmonary tuberculosis. Clinical features in; Seaton A, Seaton D ,Leitch AG, Editors. Crofton Douglass's Respiratory disease, United Kingdom: Black Well sciences 2002; 523.

\section{AUTHORS:}

1. K. Sailaja

2. H. Nagasreedhar Rao

\section{PARTICULARS OF CONTRIBUTORS:}

1. Associate Professor, Department of Pulmonary Medicine, Kurnool Medical College, Kurnool, A. P.

2. Assistant Professor, Department of Pulmonary Medicine, Kurnool Medical College, Kurnool, A. P.

FINANCIAL OR OTHER COMPETING INTERESTS: None

\section{NAME ADDRESS EMAIL ID OF THE CORRESPONDING AUTHOR:}

Dr. K. Sailaja, 50-760-118-1,

Beside Dr. Narasaram Neuroclinic, Gayathri Estates, Kurnool-518002, Andhra Pradesh, India.

E-mail: bharanikumarreddy@yahoo.co.in

Date of Submission: 30/04/2015.

Date of Peer Review: 01/05/2015.

Date of Acceptance: 18/05/2015.

Date of Publishing: 23/05/2015. 